\title{
Epistemology and Domination: Problems with the Coloniality of Knowledge Thesis in Latin American Decolonial Theory
}

\author{
Paul Anthony Chambers \\ Professor na Facultad de Educación y Ciencias Sociales do Tecnológico de Antioquia - Institucion \\ Universitaria, Medellín, Antioquia, Colômbia. \\ E-mail: paulchamberscolombia@gmail.com. ORCID: https:/ / orcid.org/0000-0003-4361-489X.
}

\section{INTRODUCTION}

Latin American decolonial theory as developed and propagated by Aníbal Quijano (2007), Walter Mignolo (2011), Enrique Dussel (2008), Ramón Grosfoguel (2013), Santiago Castro-Gómez (2005), and Boaventura de Sousa Santos (2014), among others, is increasingly influential both within Latin America and beyond. It is shaping debates in and about education and interculturality (Cortina et al., 2019; Fregoso Bailón and De Lissovoy, 2019; Kerr, 2014; Mota Díaz, 2016); in political science, where the decolonial epistemological perspective has been used to determine whether academic articles are "colonized" or "emancipated" (Baquero, Ortiz and Noguera, 2015; Rojas, 2016; Soto Pimentel, 2017); and even in the field of peacebuilding (Fontan, 2012). As put forward by the aforementioned thinkers, its core thesis of the "coloniality of knowledge" directly calls into question, or at least implicitly delegitimizes, such basic epistemological categories and aims as the belief in and search for objective truth, the idea of the rational subject, the difference between subject and object, and the universal validity of scientific knowledge. According to this thesis, such categories and aims are Eurocentric constructions that are inherently imbued with what might be termed the colonial will to dominate.

Whilst I share decolonial thinkers' critiques of colonialism, imperialism, capitalism and other forms of domination, I believe their claims about the relation between these forms of domination and Western 
epistemology and science are deeply flawed. In my view, the problematic relationship between the legacy of colonialism and the production, validation and transmission of knowledge in Latin America and elsewhere is not epistemological but political and sociological, notwithstanding decolonial claims about the inevitably political dimension of epistemology. However, my aim is not to defend a positive thesis about the problematic political and sociological dimensions of knowledge production - which are also highlighted by decolonial thinkers -, but to demonstrate why the epistemological arguments underpinning the coloniality of knowledge thesis are problematic, especially in relation to claims made about Descartes ${ }^{1}$. Whilst I agree with Sujata Patel (2014:605) that "Eurocentrism is also associated with the production, distribution, consumption and reproduction of knowledge unequally across the different parts of the world", my claim is that the decolonial thinkers analysed here fail to adequately demonstrate that Eurocentrism and the skewed and often unjust structures of global knowledge production, as well as wider forms of domination, have anything to do with Cartesian/Western epistemology and its related philosophical categories.

The article focuses on the epistemological arguments of four key Latin American decolonial thinkers who, in different ways, have shaped and developed the thesis of the coloniality of knowledge: Aníbal Quijano, Walter Mignolo, Enrique Dussel, and Santiago Castro-Gómez. The argument proceeds in the following way: it first elucidates and critiques the roots of the coloniality of knowledge thesis in an article written by Peruvian sociologist Aníbal Quijano, critiquing the subject-object "problem", allegedly derived from Descartes. It then looks briefly at how Mignolo, probably the most prominent decolonial thinker, develops Quijano's claims. I then turn to claims made about Descartes and the cogito in Enrique Dussel's liberation philosophy, which has been very influential in 'critical' social science in Latin America, before analysing Castro-Gómez's critique of what he calls the "zero point" epistemology of the Enlightenment - a thesis widely accepted within the decolonial literature and endorsed by both Dussel and Mignolo. The article concludes by highlighting some of the regressive epistemic and socio-political implications of decolonial epistemology.

Before advancing with my critique, however, it is worthwhile making clear from the outset what I am not saying in relation to knowledge production, as well as where I am in agreement with aspects of the 
coloniality of knowledge thesis. Firstly, I do not claim that knowledge production is "innocent". Knowledge is of course always produced from somewhere and is influenced by a range of contextual factors and interests, including political, social, economic and cultural ones. There are always ideological dimensions to the production of knowledge, especially social-scientific knowledge (Chambers, 2013; Harvey, 1974). Secondly, colonial assumptions and mentalities must certainly be identified and critiqued, as decolonial thinkers rightly claim. Nevertheless, as long as scientists and the public are aware of these dimensions and limitations, and when their procedures and institutions are functioning properly, it seems to me that the "scientific method" - and its underlying epistemology (a conjunction of empiricism, rationalism and critical realism) - is a powerful and valid tool for attempting to understand the natural and social worlds. However, there is no one "scientific method" that stands imperially above other forms of everyday inquiry. As philosopher Susan Haack points out in relation to the epistemological issues involved in the Daubert v. Merrell Dow Pharm Inc. court case ${ }^{2}$ :

In short, not all, and not only, scientists are reliable inquirers; and not all, and not only, scientific evidence is reliable. Nor is there a 'scientific method' in the sense the Court assumed: no uniquely rational mode of inference or procedure of inquiry used by all scientists and only by scientists. Rather, scientific inquiry must respect the desiderata, constraints, and inferences of all serious empirical inquiry; but has developed, in addition, a vast array of constantly evolving, and often local, ways and means of stretching the imagination, amplifying reasoning power, extending evidential reach, and stiffening respect for evidence (Haack, 2014:111).

\section{QUIJANO AND MIGNOLO ON DESCARTES AND THE SUBJECT-OBJECT "PROBLEM"}

The coloniality of knowledge thesis has some of its roots in a paper originally published in Spanish in 1992 by the Peruvian sociologist Aníbal Quijano, in which he coined the term "coloniality of power". The article is important in terms of its influence on decolonial thought - the Spanish version has been cited over 900 times and the English version nearly 700 times - as well as for its direct influence on arguably the major decolonial theorist, Walter Mignolo (2011: 1), for whom 
reading it "was a sort of epiphany". I also evaluate Quijano's claims about Descartes in his article "Colonialidad del Poder, Eurocentrismo y América Latina", which has been cited over 4400 times.

According to Quijano (2007:169), the repression carried out under European colonialism "fell, above all, over the modes of knowing, of producing knowledge" and was ultimately related to the Cartesian epistemology underpinning Western science. For Quijano (2007: 172), the fundamental problem with the "European paradigm of rational knowledge" is that it sees knowledge "as a product of a subject-object relation" in which "the 'object' is a category referring to an entity not only different from the 'subject' individual [sic], but external to the latter by its nature" ${ }^{\prime \prime}$. This is deemed problematic because the knowing subject "constitutes itself in itself and for itself, in its discourse and in its capacity of reflection. The Cartesian 'cogito, ergo sum', means exactly that" (Quijano, 2007:172) ${ }^{4}$, Putting to one side Quijano's highly questionable interpretation of the cogito, his complaint about Western/ Cartesian epistemology is that "it made it possible to omit every reference to any other 'subject' outside the European context" (Quijano, 2007:173), thereby invisibilizing the colonial order. This Western epistemological paradigm implies that

only European culture is rational, it can contain "subjects" - the rest are not
rational, they cannot be or harbor "subjects". As a consequence, the other
cultures are different in the sense that they are unequal, in fact inferior, by
nature. They only can be "objects" of knowledge or/and of domination prac-
tices. From that perspective, the relation between European culture and the
other cultures was established and has been maintained, as a relation between
"subject" and "object". It blocked, therefore, every relation of communication,
of interchange of knowledge and of modes of producing knowledge between
the cultures, since the paradigm implies that between "subject" and "object"
there can be but a relation of externality (Quijano, 2007:174).

However, Quijano provides no evidence or clarification in support of these claims, and his other epistemological assertions are based on a very superficial reading of Descartes, which Quijano problematically takes to be representative of "Western epistemology". No attempt is made to do justice to the complexity of Descartes' thought or its relation to its philosophical and historical context. In fact, Quijano does not even cite any works of Descartes or any other Enlightenment thinker - the article has just two references, both to works by Quijano 
himself. These omissions are significant because Quijano's aforementioned claims are problematized on only the third page of the Discourse, where Descartes writes: "It is good to know something of the customs of various peoples, so that we may judge our own more soundly and not think that everything contrary to our own ways is ridiculous and irrational, as those who have seen nothing of the world ordinarily do" (Cottingham, Stoothoff and Murdoch, 1985:113-114; hereon CSM).

As Edward Said (1979) has shown, reproachable attitudes of superiority abounded in certain European intellectual circles in relation to colonized countries and their cultural and scientific traditions. However, this is different to the much more controversial claim that such attitudes are inherently embedded in the categories of subject and object and that the propagators of Enlightenment thought, paradigmatically represented by Descartes, saw non-European cultures as epistemically inferior and "irrational". Because decolonial and postcolonial thinkers often explicitly or implicitly target the positivism of Auguste Comte - who admired Descartes and had a Eurocentric purview - for its linear view of epistemic "progress", perhaps Quijano's thesis, and the coloniality of thesis more generally, has in mind the postcolonial interpretation of Comte's work, according to which "Comtean positivism heralds scientific Reason as the superior mode of knowing, rejecting religious or metaphysical perspectives as inferior. This means that sociology, by its very 'scientific' nature, represses difference" (Go, 2016:69). Comte could be read as implying that those cultures in which theological and metaphysical traditions prevailed over the modern scientific worldview were "inferior". However, I think this would be an unfair reading. Comte was critical "of the superstitious and scholastic systems which had hitherto obscured the true character of all science" (Comte, 2000:32) and undoubtedly did believe that reason and the scientific method were superior to theology and metaphysics for providing explanations of the physical world. However, given that Copernicus', Galileo's and other scientists' work enabled humankind to see the falsity of the geocentric system - posited by theology - and the truth of the heliocentric system - as revealed by what Comte refers to as "positive philosophy" -, I don't see it as controversial to posit the superiority, in this sense, of positivism. However, this doesn't mean that Comtean positivism implies that these other forms of "knowledge", as broader ways of understanding and relating to the world, are inferior in a more general sense ${ }^{6}$. In any case, whether or not Quijano's thesis is based on such an interpreta- 
tion of Comtean positivism, my point is that Quijano's assertion about the superiority of the "European paradigm of rational knowledge" and its inherent objectification of other cultures, which has resonated throughout decolonial thought ever since, is not based on evidence drawn from Descartes' work, which undermines an important strand of the coloniality of knowledge thesis.

In relation to Quijano's historical claims, it is necessary to note that, as Jorge Cañizares-Esguerra and Marcos Cueto (2002:18-19) write:

Indigenous knowledge was lost in part because it had been inextricably woven into indigenous religions. The European conquerors persecuted practitioners of these religions and the learned indigenous elite readily embraced Hispanic acculturation. Most indigenous knowledge had been transmitted orally, and this transmission became precarious when indigenous societies came under colonial control.

Thus, according to this account, the encounter between European colonization and indigenous knowledge was more complex and nuanced than Quijano's narrative of straightforward repression implies. Certainly, the fact that indigenous knowledge was orally transmitted and that the European system of knowledge privileged the written word could be interpreted as de facto repression insofar as the colonizers' institutions and practices rendered the reproduction of this knowledge highly difficult, if not impossible. However, this is different to claiming that it was the epistemology of Europeans that led to this regrettable result - it seems more the consequence of political factors. It is also worthwhile to point out that the imposition of Christianity and the persecution of indigenous religions was not carried out by Enlightenment scientists. Of course, Christianity was the unavoidable backdrop that influenced all scientists of the day - fear of the Inquisition kept them from drawing too much from their scientific conclusions about the way the world worked -, but their epistemic approach was ultimately in radical tension with religious epistemology, something which decolonial thinkers seemingly overlook. Moreover, whilst the repression of written language did occur, which is one important way of limiting and shaping a people's means of gaining knowledge, the stock and transmission of knowledge in any society transcends language. We must also recall that it was not just the Europeans who imposed their languages and culture. As H. F. Dobyns and P. L. Doughty (cited in Mann, 2006:312) note: 
The Inkas were coolly pragmatic, efficient, and totalitarian in their policies toward conquered nations, [attempting to impose] standardization of politics, religion, customs, and language [...] They maintained order by instilling fear and using force rather than by encouraging knowledgeable participation.

This again suggests that the issue is not epistemological but political. However, if we do take it to be epistemological in some broad sense, then clearly it is not limited to "Western epistemology".

Although, as Cañizares-Esguerra and Cueto (2002:19) point out, "the Spaniards and Portuguese brought to the New World their own forms of 'Western' science and made little effort to assimilate local learned traditions", this is very different to Quijano's claim about the inherent domineering attitude supposedly secreted within subject/ object-centred Western/scientific epistemology. As Cañizares-Esguerra and Cueto note, the exception to this aversion to assimilating local indigenous knowledge was the colonists' interest in local botanical knowledge for therapeutic purposes. In order to glean the relevant information, the colonizers depended on "Indian medical experts" (Cañizares-Esguerra and Cueto, 2002:19), which suggests they had no epistemological qualms, as such, about indigenous knowledge. Such interest and exchange also call into question Quijano's (2007:174) claim that the Western subject-object paradigm "blocked [...] every relation of communication, of interchange of knowledge and of modes of producing knowledge between the cultures". The Spaniards were also astounded by the engineering, agricultural and artistic achievements of the Mexica (Mann, 2006), which implies they must at least have had some minimal respect for the inevitable knowledge (and different kinds of knowledge) these achievements implied. Thus, whilst "Science became central to imperial policies of economic control and exploitation", and "Western modes and styles of understanding the natural world became dominant and influenced all learned elite institutions in the region" (Cañizares-Esguerra and Cueto, 2002:19), it is important to differentiate between epistemic repression as a direct or indirect result of particular colonial policies - such as control of language and education - and epistemic repression deriving from something inherent in Western epistemological categories and attitudes. In relation to the latter, Quijano's claims are based on a questionable connection between the Cartesian epistemological categories of subject and object and the ideological and racist belief that Europeans were naturally 
superior to Indians and other colonized peoples who were deemed although not by all Europeans, e.g. Las Casas - to be inferior because incapable of rational thought and hence more akin to children and therefore effectively non-autonomous "objects". While such a view is infamously to be found in Kant (see Allais, 2016), there is no evidence of it in Descartes.

Whilst there is no question that many Europeans of different social and academic backgrounds held what we would today call racist ideas, Quijano's claim that these are ultimately rooted in Descartes' dualism are highly questionable. In his text "Colonialidad del poder, eurocentrismo y América Latina", Quijano (2000:224) argues the following:

\begin{abstract}
With Descartes the ancient dualist view of "body" and "non-body" mutates. What was once a permanent co-presence of both elements in each stage of the human being becomes a radical separation of "reason/the rational subject" and "body". Reason is not only the secularization of the idea of "soul" in the theological sense but a mutation into a new entity, reason/ the rational subject, the only entity capable of rational knowledge. The body was and could be nothing but an object of knowledge [...] Thus, the "body", which by definition is incapable of reasoning, has nothing to do with/is completely separate from reason/the rational subject [...] Without that "objectivization" of the "body" as "nature" and its expulsion from the realm of "spirit" it would have been difficult to attempt the "scientific" theorization of the problem of race $^{7}$.
\end{abstract}

However, the apparent separation of body and soul in Descartes is not so clear-cut and has many nuances that Quijano overlooks. For example, in the Meditations, Descartes (1960:29) says: "Nature also teaches me by these sensations of pain, hunger, thirst, etc., that I am not only lodged in my body as a pilot in a vessel, but that I am very closely united to it, and so to speak so intermingled with it that I seem to compose with it one whole". Whilst Descartes often talks about the difference and separation between mind and body, it is always necessary to bear in mind his clearly delimited philosophical aims if those passages are to be properly interpreted. For example, also in the Meditations, Descartes (1960:29) clearly states: "in talking of nature I only treat of those things given by God to me as a being composed of mind and body" (italics added). Yet elsewhere in the Meditations he also says that there is "a great difference between mind and body" (Descartes, 1960:31). However, this difference is based on Descartes' recognition 
that he can conceive of dividing up parts of his body, but not his mind; his experience of mind, of thinking, does not allow him to conceive of it in the same way as he conceives of, say, his hand or foot. Following this discussion, Descartes goes on to observe that the "nature of man [...] is composed of mind and body" (Descartes, 1960:32). Thus, Descartes' account of humankind does not simplistically separate mind and body or subject and object in the way Quijano and others claim. As Theodore Brown points out, "Indeed, Discourse on Method, which contains one of Descartes' clearest statements of metaphysical dualism, also describes the mind and body as so closely interrelated that the quality of the human mind is understood to be improvable by manipulation of the body" (Brown, 1989:325).

Quijano's claims are ultimately based on a misreading of Descartes. Whilst the Cartesian perspective does not, contrary to Quijano's assertions, neglect or deny the importance of the body or reduce it to the state of a mere object, it does not make physical qualities essential characteristics of what constitutes the human and, partly for this reason, it was actually seen by some Enlightenment philosophers as providing a barrier to the kind of racist views found in the works of David Hume and John Locke, as Harry Bracken (2002:122-126) points out .

Quijano (2000:217) also implies that Descartes' ideas are ultimately responsible for the domination of women:

That new and radical dualism affected not only racial relations of domination but also the older sexual relations of domination as well [...] It is likely that $[. .$.$] the idea of gender was elaborated after the new radical$ dualism came into force as part of the Eurocentric cognitive perspective $e^{8}$.

However, as Descartes scholar Stephen Gaukroger (1997:4) writes:

Cartesianism was in fact developed into a specific social philosophy at an early stage, and Francois Poulain de la Barre, in his Discours physique de moral de l'égalité des deux sexes, où l'on voit l'importance de se défaire des préjugez (1673), applied the 'method of doubt' and the doctrine of clear and distinct ideas to the prejudices of the day, and unmasked the falsity of one of the greatest of these prejudices, the inequality of women, offering one of the first and most articulate defences of feminism in the early modern era. 
In conclusion, Quijano's claims about the nature of Descartes' epistemology do not withstand scrutiny, which inevitably undermines his claims about the supposed impact of Cartesian/Western epistemology in relation to social and political domination in Latin America. Yet even supposing Quijano's reading of Descartes were correct, the fact is that he fails to explain just how Cartesian epistemology has had the impact he claims it has.

Like Quijano, Walter Mignolo also makes much of the supposed problem of the subject-object relation, which he also deems to originate in Descartes. As with Quijano, Mignolo's understanding of Descartes is based on an extremely shallow reading. For example, in The Darker Side of Modernity, Mignolo (2011:81) says that the "European system of knowledge" was "built on the premise that [...] every one [sic] in the world should believe (after Descartes) that they think and therefore exist". But nowhere does Descartes state or even imply this, and European philosophers and scientists certainly did not interpret Descartes in this shallow and erroneous way. On only the second page of the Discourse on Method Descartes clearly contradicts Mignolo's assertion: "My present aim, then, is not to teach the method which everyone must follow in order to direct his reason correctly, but only to reveal how I have tried to direct my own" (CSM:112). Of course, Descartes hoped to convince his readers of the power of his method, yet this is different to adopting the kind of immodest arrogance imputed to him. Such disregard for serious interpretation of the work and motivations of Descartes should make us very wary of the alleged epistemological problems that Mignolo claims derive from it. As José Domingues (2009:210) points out, Mignolo ignores, or at the very least fails to emphasize, the fact that the revolution of modern thought represented by Descartes was an important liberatory moment: "Mignolo concentrates exclusively on 'originary peoples', overlooking the emancipatory aspects of modernity".

Based on his highly questionable interpretation of Cartesian epistemology, Mignolo (in a different text) highlights the apparent differences between the Aymara idea of the knowing subject as at one with the natural world and the alleged modern idea of the knowing subject as entirely separate from it. The claim is that, for some reason, modern Western philosophers/scientists did not or could not see themselves as part of nature, while indigenous people did and continue to do so. Putting to one side the fact that this is both a romanticized picture of indigenous people who are often deemed, in the eyes of Westerners 
like Mignolo, to be inherently "at one" with nature or the "cosmos", as well as a common misreading of Descartes' dualism (see Brown, 1989), the difference that Mignolo claims to detect between the socalled modern scientific and Aymara views of the world is extremely tenuous. To claim, on the basis of a few metaphors taken from reports about the Aymara conceiving of knowledge as the "heart of a tree" or the "stone of a peach", that it is "difficult in this context to think about the distinction between the knowing subject and an object that is known" (Mignolo, 1995:15) is hardly convincing and seems a feeble attempt to find evidence to fit his decolonial epistemological theory.

Mignolo's claim also leaves a lot to be explained about how all humans - whether Aymaran or European - make their way in the world without making some sort of differentiation between subject and object. For example, on what basis do humans choose to kill animals to eat instead of each other, if not through some epistemological scheme of subject and object, some kind of epistemological and ethical distancing mechanism? Although probably all human cultures have such a mechanism, it is surely the case that the distinction humans make between subject and object is fluid and flexible/inconsistent, and no doubt differs between cultures. The Aymara perhaps do have a smaller gap between subject and object than most Westerners. In the West this fluidity is evidenced in the abolition of slavery, which is to say in the ethical-epistemological recognition that Africans and other enslaved people were moral and cognizing subjects, not objects. The gaining popularity of vegetarianism and veganism in the West is further evidence of epistemological and ethical flexibility/inconsistency, which contradicts the notion that "Western epistemology" is based on a rigid dichotomy between subject and object.

We might also ask why there would be movements in the West to protect and preserve the natural world if so-called Western epistemology renders one unable to conceive that we are, ultimately, a part of nature. Mignolo's claims in relation to this subject-object issue also fail to account for why some cultures in the West, for example the Amish people, are equally as connected to the natural world as some non-Western indigenous people, yet have been brought up entirely within a Western epistemological perspective. In sum, contrary to what Quijano and Mignolo claim, there is not a radical divide - certainly not an absolute one - between Aymara or any other indigenous people's epistemology and that of Westerners. Nevertheless, Quijano's and 
Mignolo's unargued claims about Descartes and the socio-political implications of his subject-object/mind-body dualism are seemingly deemed not to need justification, which might well be due to the fact that such claims about Descartes had already long been established as received truth in Latin American liberation philosophy, an issue to which I now turn.

\section{ORIGINS OF DECOLONIAL EPISTEMOLOGICAL CLAIMS IN DUSSEL'S LIBERATION PHILOSOPHY}

Enrique Dussel is an exiled Argentine philosopher and one of the founding exponents of Latin American liberation philosophy. As a victim of one of the US-backed national security states in Latin America, Dussel's abhorrence of imperialism is entirely understandable. The Latin American liberation movement called into question the validity of a certain way of doing philosophy and social science that it deemed to be conceptually complicit in legitimizing and perpetuating a "Eurocentric" imperialist worldview. However, I would suggest that liberationists' political passion and understandable clamour for justice led to some highly exaggerated claims about the relation between European philosophy (specifically epistemology) and various forms of imperialism, which have ultimately influenced the current decolonial tendency in critical Latin American thought.

As Santiago Castro-Gómez (2011:38) writes:

Before Lyotard, Vattimo and Derrida in Europe, the Argentine Enrique Dussel signalled the consequences of Heidegger's critique of Western metaphysics and drew attention to the intrinsic relation between the modern subject of the Enlightenment and European colonial power. Behind the Cartesian ego cogito, which inaugurates modernity, there is a hidden logocentrism through which the enlightened subject divinizes itself and becomes a kind of demiurge capable of constituting and dominating the world of objects. The modern ego cogito thus becomes the will to power: "I think" is equivalent to "I conquer", the epistemic foundation upon which European domination has been based since the $16^{\text {th }}$ century ${ }^{9}$. 
However, as we will see, Dussel's argument in support of the claim that there is a direct relation between Cartesian epistemology and imperialist and other forms of domination is extremely weak, amounting to no more than a combination of highly questionable assertions.

Dussel's unfounded claims about Descartes were first made in his Para una Destrucción de la Historia de la Ética (1969), where he critiqued Descartes for laying the groundwork for the fundamental "problem" with "modern subjectivity": that the "bourgeois" subject exercises a "will to dominate nature" (citing Scheler) and "does not contemplate the world but instead sees it as an object of domination" (Dussel, 1969:77).

Rather convolutedly, Dussel (1969:82) writes:

Since Descartes, passing through Kant, Nietzsche and culminating in axiological ethics (and to some degree also in Sartre, for whom man is a subjectum with limitless freedom), the subjectum has been imposed as homo faber due to the act of representation that "from itself can set something before itself", objectify itself ${ }^{10}$.

According to Dussel (1969:78-79), in this epoch "mankind" has become "savers, producers, possessors", and the ethos of "merciless individualism" "comprehensively grounds a radical attitude, which is also fundamental to modern science: that of the mathematical mode (which is not merely mathematical) of being in the world". Dussel (1969:79) goes on to claim that

Man modern lives naively in the "world of daily routine" and has no selfawareness of his own attitudes. The mathematical position one adopts towards entities is that of already knowing them (such as the axioms of science, for example) and of being resolved only to learning them .

In my view, these claims are historically questionable, sociologically simplistic, philosophically confused and untenably generalizing. Moreover, Dussel's sweeping generalization about "modern man's" uncritical nature is also contradictory. Dussel is explicit about adopting a so-called "critical" approach to philosophy, only to fall into the most uncritical generalizations about an entire epoch and people. 
After this, drawing entirely on Heidegger - with no argument as to why we should pay attention to Heidegger's convoluted account of being and the self -, Dussel (1969:80) claims that modern man is the result of the disintegration of man as "being-in-the-world", leading to the formation of the "metaphysical a priori of the subject". According to Dussel (1969:81), "In considering modern man as a subjectum, this objectivizes his own body as an object, as a machine, and with it the 'world' is reduced to an empty 'space' to be filled by extended bodies". One would be hard pressed to find a more facile and reductive interpretation of modern accounts of the subject. Nevertheless, the self has, so Dussel (1969:82) holds, been "reduced" from a beingin-the-world with a telos - Dussel does not specify what this alleged ultimate end of mankind is or how one could know it, beyond citing Heidegger - to a "project that is represented by me and for me. Man is cast adrift". So far there is no philosophical argument, but simply a set of pseudo-profound assertions that depend for their power of conviction on their being couched in often pretentious sounding constructions amidst smatterings of German and quotes from Heidegger.

Dussel (1969:137) also suggests that the Kantian subject - which he considers, along with Descartes' account, to be the definitive modern account of the subject - "puts" or "sets forth" the objects it thinks it perceives as separate from itself. Seemingly confusing representation with the act of creation, Dussel (1969:82, footnote 116) further claims that "in modernity, man is the measure of all things insofar as he represents objects and therefore constitutes things in themselves"11. This, so Dussel tells us, is totally different to the sense in which Protagoras had understood man to be the measure of all things, because in the latter's case this was true only in the sense that man "discovers" being. However, first, the notion that the modern individual actually constitutes the objects he or she perceives is untenable; even Berkeley's idealism does not imply this (see Russell, 1945). In fact, this implication is much more prevalent in the postmodern philosophy that Dussel defends - he explicitly states that liberation philosophy is postmodern in his Philosophy of Liberation. Postmodern philosophy is pervaded by constructivist epistemologies that are vulgarizations ${ }^{12}$ of the classic pragmatist theory of knowledge associated with James, Peirce and Dewey, and which, as Bertrand Russell observes, ultimately provides an epistemological rationale for humankind's exercise of power over nature and other human beings. In contrast, Russell's (2009:186) own modern (empiricist), "foundationalist" epistemology, in his view, sets 
limits to human power insofar as it recognises that human pretensions are limited by external reality and humans cannot simply invent or "constitute" it. Second, this interpretation certainly misunderstands the modern scientific worldview, which at least since Francis Bacon has been based on an epistemology that attempts to discover objective truths about the world (see Wootton, 2015). Ultimately, it seems Dussel's interpretation of modern subjectivity, science and epistemology depends on the questionable assumption that the modern subject is at root a dominator whose only relation to other entities (no matter what they are, whether gold or people) is one of domination and control.

This view of the modern subject is given a further twist in Dussel's influential Philosophy of Liberation, first published in 1977, in which he continues the theme of demonizing Descartes and European philosophy by way of more unfounded sweeping claims and generalizations. One of its main theses is that the "I conquer" of the conquistadors is the "practical foundation of 'I think'" (Dussel, 1985:3):

From the "I conquer" applied to the Aztec and Inca world and all America, from the "I enslave" applied to Africans sold for the gold and silver acquired at the cost of the death of Amerindians working in the depths of the earth, from the "I vanquish" of the wars of India and China to the shameful "opium war" - from this "I" appears the Cartesian ego cogito (Dussel, 1985:8).

There is no further explanation or argument. Just pure, unsupported assertion. Considering the audacity of such a thesis one would expect a philosopher who claims his discourse "will be erudite in the extreme" (Dussel, 1973:13) to actually provide an argument based on evidence as opposed to an argument based on appeal to the authority of Heidegger. In similar vein, Dussel (1985:32-33) also claims that "Westerners naively take for granted that their culture, political power, and military domination are justified, and that they spread democracy and liberty on earth. This mentality is part of a naive everydayness that manipulates whole populations". Again, it is hard to take seriously such wholesale generalizations. For sure, many Westerners undoubtedly are uncritical about their way of life and their political and economic systems, but it is equally the case that many Westerners (Bertrand Russell for one) are highly critical of their everyday reality. 
In a 2008 article titled "Meditaciones Anti-cartesianas", published in English in 2014, Dussel imputes to Descartes a weighty responsibility for socio-political and patriarchal domination in Latin America and elsewhere in the global periphery. Under the subheading "Ratio mathematica, epistemic rationalism, and subjectivity as foundation for the political domination of colonial, colored, female bodies", Dussel claims that Descartes' dualistic conception ${ }^{13}$ of the body as a machine provided the grounds for the dehumanization of the human body and for subsequent colonial domination:

That pure machine would not show skin color or race (it is clear that Descartes thinks only from the basis of the white race), and nor obviously its sex (he equally thinks only on the basis of the male sex), and it is that of a European (he doesn't sketch nor does he refer to a colonial body, an Indian, an African slave, or an Asian). The quantitative indeterminacy of any quality will also be the beginning of all illusory abstractions about the "zero point" of modern philosophical subjectivity and the constitution of the body as a quantifiable commodity with a price (as is the case in the system of slavery or the capitalist wage) (Dussel, 2014:21).

Despite the fact that this somewhat confusing passage ${ }^{14}$ concludes a lengthy section on Descartes and the cogito, there is no historical or philosophical argument that logically justifies such an outlandish assertion, and there is no attempt to contextualize and judiciously interpret Descartes' discussion in terms of his, at the time, understandable mechanistic explanation of bodies (human and celestial). There is discussion of Descartes' education under the Jesuits and a brief, intellectually decontextualized account of Descartes' views about the nature of the soul as distinct from the body, but there is nothing in the way of an actual argument to support the claim that Descartes' method of philosophizing and the cogito provided the epistemological foundation of slavery or the capitalist wage. Nowhere does Dussel tell us why, given Descartes' stated modest philosophical objectives ${ }^{15}$, he should have made reference to colonial or female bodies or slaves. Assuming for the sake of argument that Descartes' influence was such that it extended beyond scientific pursuits and the scientific establishment to the political arena and provided the basis for a multitude of political and social evils, Dussel fails to demonstrate or explain how Descartes' cogito had such power. Nevertheless, this claim is echoed throughout the decolonial literature. 


\section{THE MYTH OF THE "ZERO POINT": MISREADING DESCARTES AND HUME}

I now turn to influential Colombian philosopher Santiago CastroGómez and his thesis of the "zero point", which Dussel and other major decolonial figures endorse. According to Walter Mignolo (2011:81), "Western epistemology [...] is the epistemology of the zero point". He adds:

The hubris of the zero point, or epistemology of the zero point, is a key concept to understand how the theo- and ego-politics of knowing and knowledge operate, and to grasp the challenge presented by the emergence of the geo- and body-politics of knowledge, which delink from the hubris of the zero point (Mignolo, 2011:xxxiii).

However, as we will see, the alleged importance of the "zero point" is clouded by its being difficult to clearly define, which is ultimately due to its not being backed up with any serious argument based on textual or historical evidence. Castro-Gómez's thesis is found in his work La Hybris del Punto Cero. Ciencia, Raza e Ilustración en la Nueva Granada, 1750-1816, which focuses very specifically on how "the European Enlightenment was translated and expressed in Colombia" (Castro-Gómez, 2005:15). However, despite this narrow contextual focus, Castro-Gómez makes a series of generalizing assertions about the European Enlightenment and equates the racist attitudes and practices of the Spanish Jesuits in New Granada with the Enlightenment project as a whole.

Castro first discusses the zero point thesis in linguistic terms, claiming that the "language" of science was aimed at avoiding the "inexactitude" of everyday language and that the ideal of the "Enlightenment scientist" is to "take epistemological distance" from this vernacular language. According to Castro-Gomez (2005:14),

Unlike other languages, the universal language of science has no particular place on the map, but is rather a neutral platform for observation from which the world can be named in its very essence. Produced not within the world of everyday life (the lifeworld) but from a zero point of observation, scientific language is understood in the Enlightenment to be the most perfect of human languages because it most purely reflects the universal structure of reason. 
Yet this is a strange way of talking about science, especially in the Enlightenment period, in which many scientific findings were published not in Latin but in the vernacular. As Margaret Jacob (2010:7) notes, "Many practitioners of the new science broke with tradition even in the language they used to communicate their findings. Instead of using Latin [...] they turned to their native languages" ${ }^{\prime 16}$. It is also misleading to claim that science aims to know things in their "essence", to penetrate to the core of the phenomena it studies. As John Stuart Mill put it in his exhaustive review of Comte's positivist approach to studying the social world, Comte held that "The laws of phaenomena [sic] are all we know respecting them. Their essential nature, and their ultimate causes, either efficient or final, are unknown and inscrutable to us" (Mill, 2005:3). Moreover, this "conception of human knowledge $[\ldots]$ has been virtually acted on from the earliest period by all who have made any real contribution to science, and became distinctly present to the minds of speculative men from the time of Bacon, Descartes, and Galileo" (Mill, 2005:3). Descartes was also sceptical about being able to know things in themselves precisely because our senses, the medium through which we know, can deceive us.

Castro-Gómez's account of Enlightenment epistemology and science also extends to a discussion about the legitimacy of universal classificatory schemes, which he claims have displaced and disparaged local forms of naming and knowing. For example, he asserts that the Swedish naturalist Carl Linnaeus declared "in effect, that all names used before him - in all places and at all times - for classifying the members of the plant kingdom were illegitimate" (Castro-Gómez, 2005:207) and alleges that, for Enlightenment science, local, indigenous accounts of knowledge "would have to give way to the hegemony of a single kind of true knowledge, that provided by the scientific-technical rationality of modernity" (Castro-Gómez, 2005:206). Furthermore, in order to achieve this knowledge, the scientific paradigm would have to effect a "rupture with the smells, colours, flavours and other 'barbaric' ways of seeing the world" (Castro-Gómez, 2005:216; italics in original). Yet Castro-Gómez provides no evidence that Linnaeus or anyone else actually held such beliefs. Neither does he provide an explanation as to why Linnaeus or anyone else would hold these ridiculous views, aside from implying that all Enlightenment figures for some reason had a monolithic, totalitarian view of the world according to which any proposition about the world and any cultural practices that had not been verified by the scientific method had to be deemed 
"invalid" and eradicated. But of course, this is highly problematic; not only does it portray Enlightenment scientists as obsessive, calculating machines devoid of humanity, it also logically implies that they must have deemed many of their own beliefs, non-scientific naming schemes and cultural practices invalid and illegitimate.

It is this caricature of Enlightenment epistemology and science that provides the framework for his thesis of the "zero point", which Castro-Gómez (2005:18) describes in the following way:

It is the idea that an observer of the social world can stand on a neutral platform of observation and at the same time not be observed from any angle. Our hypothetical observer would thus be in a position to take a sovereign's eye-view of the world whose power lies precisely in not being observed or represented. The inhabitants of the zero point (Enlightenment scientists and philosophers) are convinced that they can acquire a perspective that itself cannot be observed from any point of view.

Castro-Gómez (2005:24) adds that "No one expressed this aim with as much clarity as René Descartes", which is a highly questionable interpretation of Descartes' philosophical aims and motivations. He claims that Descartes' method of hyperbolic doubt, in which he put into doubt all opinions and knowledge that he had previously held unquestioningly but which he had shown (to himself) to be far from securely based, is the cornerstone of Western epistemological hubris. He writes:

This absolute point of departure, in which the observer discards all previously held knowledge - effectively becoming a blank slate - is what we will call the hubris of the zero point. To start all over again means having the power to name the world for the first time, to establish the parameters of legitimate and illegitimate knowledge, as well as to define which behaviours are normal and which are pathological. Hence, the zero point refers to an absolute epistemological starting point as well as the economic and social control of the world. To situate oneself at the zero point is equivalent to having the power to institute, represent, and construct a vision of the social and natural world that is legitimated and promoted by the state (Castro-Gómez, 2005:25). 
However, this is problematic for several reasons. First, it ignores the fact that Descartes did not hold to the doctrine of the blank slate tabula rasa, which is to be found in the epistemology of John Locke-, but to the doctrine of innate ideas. This doctrine can be interpreted as implying that the knowing subject does not have the epistemic power to simply arrange and represent all aspects of the natural world as they would wish: human knowledge and representation are limited by pre-given, non-humanly created cognitive capacities. Second, it reads into the cogito an epistemic arrogance that is not there. As Stephen Gaukroger (1997:340) points out, "Descartes' aim in introducing hyperbolic doubt was to show that we cannot legitimate our knowledge claims by relying wholly on our own resources". Moreover, as Descartes writes in the Discourse:

My plan has never gone beyond trying to reform my own thoughts and construct them upon a foundation which is all my own. If I am sufficiently pleased with my work to present you with this sample of it, this does not mean that I would advise anyone to imitate it... The simple resolution to abandon all the opinions one has hitherto accepted is not an example that everyone ought to follow (CSM:118).

Third, it is based on making highly contentious, unargued extrapolations from Descartes' epistemological aims - and their implications - to much wider political and economic aims and implications.

Ultimately, the thesis trades on the erroneous interpretation of Descartes' aims, motives and methods that we find throughout the decolonial literature which, as we have seen, has its roots - in Latin America - in Dussel's work. While Descartes certainly thought the operative principles of the natural world were universal, he made no claims about seeking universally valid knowledge of the social world. Descartes sought some secure basis for tentatively building up knowledge about the world, some of it through empirical experimentation and not always through pure deduction - as decolonial thinkers claim (see Castro-Gómez, 2005:26). One of his principal aims was to combat scepticism (Bracken, 2002), which in Descartes' social context was also used by different sides in the religious disputes of the period to undermine others' dogmatic claims in order simply to assert equally dogmatic alternative claims. Ironically, given decolonial assertions, as Harry Bracken (2002:113) puts it, "The Cartesian theory of knowledge in effect removes the privileged role of the Church (and all other 
authorities)". A more careful reading of Descartes thus shows that, far from being an ally of power and domination, the Cartesian approach actually undermines dogmatic claims of whatever provenance. Without doubt, Descartes would have assumed that the laws of nature operate universally, but this is hardly controversial or imperialistic. It is also very different from making claims about alleged universal social laws. Yet it is precisely this distinction that the zero point thesis overlooks. It lazily elides the different epistemological approaches of the natural and social sciences - probably due to the usual set of careless generalizations about "positivism" in social science -, drawing a tendentious continuity between Descartes' aims in the natural sciences and later thinkers' forays into ethics and politics, which would feed into the social sciences.

It also glosses over the significant differences between rationalist (Cartesian) and empiricist epistemologies, and talks of "Western epistemology" as if it were all of a piece. This is factually wrong and philosophically inexcusable, especially when one is making such controversial claims ${ }^{17}$. Furthermore, the differences between them are philosophically relevant to the issue of racism that Castro-Gómez and other decolonial thinkers are concerned with. As I mentioned in relation to Quijano's claims, Harry Bracken points out that the empiricist epistemological framework actually facilitated the legitimation of racist positions, while the Cartesian rationalist approach was seen by some Enlightenment philosophers as a barrier to them (see Bracken, 2002:122-126). This undermines decolonial claims that so-called Western epistemology is inherently racist (e.g. Mignolo, 2011:201; Grosfoguel, 2013).

In making his case about the problematic character of Enlightenment epistemology and science, Castro-Gómez discusses the work of David Hume, whose "science of Man" he sees as emblematic of the zero point hubris he imputes to the Enlightenment project as a whole - and to contemporary social science. According to Castro-Gómez, Hume makes questionable universal claims about human nature, which is another one of the bugbears of the decolonial perspective. Because Hume says he aims to describe mankind as it is in fact and not as it should be, and therefore puts to one side moral, religious or metaphysical accounts of mankind, Castro-Gómez (2005:27) deems this to be typical zero point epistemology. Yet one could argue that, precisely because Hume apparently questions - there is controversy on this point - the inference of ought statements from is premises, his approach is at least potentially 
"critical". Certainly, Hume might well end up describing the alleged facts of human nature in such a way that they just so happen to be the characteristics of men within Hume's own social context and class, implying that men ought therefore to aspire to that particular social order. However, Hume's own caveats and his explicit critique of the is-ought relation at the very least enable his readers to use these as criteria for critically evaluating Hume's claims. For example, Hume (2009:12-13) says:

And though we must endeavour to render all our principles as universal as possible, by tracing up our experiments to the utmost, and explaining all effects from the simplest and fewest causes, it is still certain we cannot go beyond experience; and any hypothesis, that pretends to discover the ultimate original qualities of human nature, ought at first to be rejected as presumptuous and chimerical.

Unfortunately, Castro-Gómez ignores these important nuances. He also misreads Hume, imputing to him views that make him sound much more like an apologist for individualist capitalism than he arguably was. For example, he claims that for Hume human actions "are not motivated by reason but by interest in self-preservation" (CastroGómez, 2005:28). However, it would be more accurate to say that for Hume what drives human action are the passions, which include selfpreservation as well as other interests and emotions. Castro-Gómez then quotes the following passages from Hume (2009:745-802):

Now it appears, that in the original frame of our mind, our strongest attention is confined to ourselves; our next is extended to our relations and acquaintance; and it is only the weakest which reaches to strangers and indifferent persons [...] Nothing is more certain, than that men are, in a great measure, governed by interest, and that even when they extend their concern beyond themselves, it is not to any great distance; nor is it usual for them, in common life, to look farther than their nearest friends and acquaintance ${ }^{18}$.

Castro-Gómez (2005:28) then summarizes Hume's thesis:

The first "law of human nature" discovered by the science of man is thus the following: natural instinct ineluctably leads man to prefer what is familiar and close to him over what is strange and distant. Nothing in his 
nature makes him want to "extend his concern beyond himself", such that all his actions, even the most impersonal and altruistic, only have meaning insofar as they benefit himself.

According to Castro-Gómez, the upshot of this is that Hume basically elaborates a theory of human nature that legitimizes the dominant economic and social order, which is effectively taken to be a universal law: "The universality of these phenomena is due to the fact that they are grounded in an unvarying tendency of human nature that had already been observed by Hume: the need to satisfy the interests of those closest to us over strangers" (Castro-Gómez, 2005:30).

However, Castro-Gómez clearly misreads the passages cited. Hume does not say that man's natural instinct is to favour one's interests over others or that there is nothing in his nature that leads him to extend his concern beyond himself. All Hume states is that "our strongest attention is confined to ourselves" (Hume, 2009:745). Whilst this is the dominant tendency in our nature, it is not the only one; it is equally part of our nature to extend our concern to others, just not in the same degree. I would suggest that this is an accurate observation by Hume, who goes on to point out that anyone who only acted according to either one of these tendencies, i.e. always favouring their own and their family's and friends' interests, or who only favoured the interests of others beyond themselves and their immediate circle, would be "vicious and immoral" (Hume, 2009:746).

In conclusion, Castro-Gómez's claims about Hume, which he uses as evidence in support of his zero point thesis, distort what Hume actually wrote. This is plausibly due to Castro-Gómez first elaborating the idea of the zero point and then seeking examples to confirm it, which, ironically, would be similar to the alleged modern method that Mignolo criticizes (see Mignolo, 2011:99). To summarize, as a philosophical thesis, the notion of the zero point is incoherent, and, as a historical thesis about the approach and attitude of Enlightenment thinkers, it is highly questionable. Nevertheless, despite these serious problems, the decolonial perspective has become increasingly influential, not only in Latin America. In the following and final section, I shall briefly summarize what I believe to be just a few of the regressive implications of the decolonial epistemological perspective. 


\section{THE PROBLEMATIC SOCIO-POLITICAL IMPLICATIONS OF THE DECOLONIAL PERSPECTIVE}

The misguided criticism of scientific rationality and epistemology in the decolonial literature, which commits the fallacy of confusing science as a method and epistemic attitude with the ideological use and application of science, serves to delegitimize one of the most important tools available for analysing and challenging power. It is the failure of decolonial thinkers to make this distinction that leads them to see science as aspiring to universal domination, which contrasts with Bertrand Russell's view that "Science is empirical, tentative, and undogmatic; all immutable dogma is unscientific" (Russell, 2009:441). Yet as Russell (1945:494; italics added) also points out,

The philosophies that have been inspired by scientific technique are power philosophies, and tend to regard everything non-human as mere raw material. Ends are no longer considered; only the skilfulness of the process is valued. This also is a form of madness. It is, in our day, the most dangerous form, and the one against which a sane philosophy should provide an antidote.

Unlike decolonial thinkers, however, Russell does not locate the problem of the misuse of scientific technique in the realm of epistemology.

Decolonial thinkers also overlook how scientific thinking and its underlying epistemology have liberatory potential. For example, in her study of scientific knowledge in the context of the British Empire in Africa, Helen Tilley (2011:24) points out "the subversive relationship that could exist between science and empire, particularly in the era of late European colonialism", adding that "scientific research began to decolonize Africa by challenging stereotypes, destabilizing Eurocentric perspectives, and considering African topics on their own terms". Whilst science is inextricably bound up with empire and current-day capitalist exploitation, as decolonial thinkers rightly emphasize, it is equally the case that scientific epistemology is a potent tool for analysing all kinds of truth claims and practices, and therefore also for critiquing the dominant order.

Another problem with the coloniality of knowledge thesis is that, in the works of the authors analysed here, it is based on sweeping generalizations, non-sequiturs, wild extrapolations, disregard for carefully 
reasoned argument, context and nuance, and uses opaque, often pretentious language. As Bolivian activist-academic Silvia Rivera Cusicanqui (2012:98-102) observes, the works of Mignolo and Dussel, among others, have created

a jargon, a conceptual apparatus, and forms of reference and counterreference that have isolated academic treatises from any obligation to or dialogue with insurgent social forces. Walter Mignolo and company have built a small empire within an empire, strategically appropriating the contributions of the subaltern studies school of India and the various Latin American variants of critical reflection on colonization and decolonization [...] Neologisms such as decolonial, transmodernity, and eco-si-mía proliferate, and such language entangles and paralyzes their objects of study: the indigenous and African-descended people with whom these academics believe they are in dialogue. But they also create a new academic canon, using a world of references and counterreferences that establish hierarchies and adopt new gurus: Mignolo, Walsh, Enrique Dussel, Javier Sanjinés.

A further problem is that, although decolonial thinkers are explicitly concerned about transforming social injustices, their epistemological perspective ultimately leads to relativism ${ }^{19}$, which is a problematic basis for social critique and analysis. As Alan Sokal and Jean Bricmont point out in their now classic critique of postmodernism:

If all discourses are merely "stories" or "narrations", and none is more objective or truthful than another, then one must concede that the worst sexist or racist prejudices and the most reactionary socioeconomic theories are "equally valid", at least as descriptions or analyses of the real world (assuming that one admits the existence of a real world). Clearly, relativism is an extremely weak foundation on which to build a criticism of the existing social order (Sokal and Bricmont, 1999:196).

Walter Mignolo is one decolonial thinker who adopts an openly relativist stance, pointing out that his strange alternative epistemological principle "'I am where I think' is one basic epistemic principle that legitimizes all ways of thinking" (Mignolo, 2011:81) ${ }^{20}$. Although Mignolo talks about legitimizing all ways of thinking, not specific thoughts, it still raises concerns. For example, are political societies and social movements to make decisions of public interest on the basis of hallucinogenic rituals carried out by shamans, by consulting the tarot, or by the public (universal) standards of rational, evidence- 
based inquiry? According to the decolonial perspective, these must all be deemed equally valid. This is not to imply that such rituals and practices do not embody forms of knowledge that are valid in certain contexts for certain groups of people. It is merely to say that when it comes to the plural, public world of politics and political critique, scientific knowledge and logical, evidenced-based reasoning provide a necessary baseline.

Mignolo also states that "I am where I do" flatly rejects the assumptions that rational and universal truths are independent of who presents them, to whom are they addressed, and why they have been advanced in the first place" (Mignolo, 2011:99). But such a position simply undermines itself - if there is no independent standard of truth, what makes Mignolo's own historical accounts of modernity true? Are they true only for people who accept his premises, a bit like religious dogma? If there are no cross-cultural epistemological standards by which arguments and evidence can be objectively evaluated, why does Mignolo write academic books aimed at a global public? More importantly, how are Latin American social movements supposed to make decisions about how to resist Western imperialism if its truth and the truth of their analyses are dependent on who says it or to whom they are addressed? How can they build "inter-connections from the subaltern perspective" (Mignolo, 2011:235) on the basis of this relativist, postmodern epistemology? In order to build associations across the diverse, global "colonial matrix of power" (Mignolo, 2011:xvi), Haitians, Guatemalans, Bolivians and many others marked by colonial domination need some non-relativist epistemological basis for critiquing and analysing the world and for communicating ideas and concepts.

Although fellow decolonial thinker Santiago Castro-Gómez correctly points out that Mignolo's position "Could lead to the legitimation of all kinds of political and moral authoritarianism just because they are rooted in non-Western traditions and 'knowledges otherwise'" (Castro-Gómez, 2011:74, italics in original), it is difficult to see on what basis he can identify and distinguish between legitimate and illegitimate practices. In order to be able to do this he himself needs some epistemological ground on which to stand that is not culture-bound or relative to some "discourse" or set of "discursive practices" - to use the Foucauldian terminology that Castro-Gómez prefers. This is because the external analysis and evaluation of some cultural practice as "authoritarian" implies some trans-cultural standard, something 
which the decolonial perspective would appear to disallow. Ultimately, a relativist epistemology seriously undermines decolonial claims and analyses. For all their critique of supposedly Eurocentric universalism and 'positivism', postcolonial and decolonial analyses and claims surreptitiously depend on certain epistemic categories and modes of reasoning associated with the Enlightenment and the positivist tradition in the social sciences. As Julian Go (2016:73) points out,

the very premise of the postmodern-postcolonial critique - that is, that knowledge and power are connected - is itself a sort of positivist assertion that inscribes a truth claim and implicit if not explicit causal explanation... To make even the most basic claim that knowledge fueled imperialism is to summon the basic tenets of social science. It is to posit a realist social ontology: it is to insinuate that there is a world consisting of some regularities or patterns (even if they are not total or universal) that is observable and knowable.

\section{CONCLUSION}

In sum, the (il)logic of the decolonial epistemological perspective as synthesized in the works of the key theorists analysed seems to be the following:

a) Truth claims about the world, and therefore true sociological and political analyses, depend for their validity not on correspondence to objective social reality - objective but nonetheless socially constructed -, but on where and by whom they are made from within the "colonial matrix of power" - although decolonial thinkers do not make clear what the criteria are for judging a truth claim to be valid. I must clarify that I am not saying there is a clear cut 'scientific method' that can guarantee a totally objective explanation and account of the social world uncontaminated by ideological interests, cultural prejudices, etc. What I am saying is that Mignolo's and other decolonial thinkers' epistemic relativism (for example, that of Sousa Santos) undermines itself and cannot help the oppressed to analyse, comprehend and cogently critique social reality. The philosopher Susan Haack, known for her "foundherentist" epistemological theory - a kind of middle way between oft-maligned foundationalism and unanchored coherentism (Haack, 1993) - provides a clearer way of articulating that social reality is always constructed from somewhere by someone or some group, whilst also not being simply relative to either but, in an important sense, "objective": 
The world - the one, real, world - is largely independent of us. Only "largely", not "completely", independent of us, because human beings intervene in the world in various ways, and because human beings and their physical and mental activities are themselves part of the world... We humans describe the world, sometimes truly, sometimes falsely. Whether a (synthetic) description of the world is true depends on what it says, and on whether the world is as it says. What a description says depends on our linguistic conventions; but, given what it says, whether it is true or it is false depends on how the world is. True, some descriptions describe us, and some describe things in the world that we made; and whether such a description is true or is false depends on how we are, or on how the things we made are -for such descriptions, that is the relevant aspect of "how the world is". But whether even such a description is true or is false does not depend on how you or I or anybody thinks the world is (Haack, 1998:156-157).

b) Any claim that purports to be valid beyond a certain geo-cultural location is ideological - in the sense of falsely universalizing or representing one's interests as akin to others' interests - or part of a particular configuration of power relations specific to a certain context, because universal categories and claims are part of the zero point "episteme" of modernity.

c) There is no such thing as a trans-cultural human nature and "no universal common ground of experiences" (Mignolo, 2011:191). According to Mignolo, critical theory doesn't go far enough in its critique of the subject. He writes,

The problem with Horkheimer's argument is that his subject is a modern subject, de-racialized, de-sexualized, gender-neutral, and unaware that such a subject dwells in Europe, better yet, Germany, and not in the City of Singapore, Tehran, or La Paz, where the issues, problems, and knowledgemaking have different needs, genealogies of thoughts, affects, and problems (Mignolo, 2011:xxiv).

The problem with this is that it can always be taken a step further back: to a specific barrio in Tehran or La Paz, to a block or street, to a specific house, to a certain family, to a particular individual, where "the issues, problems, and knowledge-making have different needs, genealogies of thoughts, affects, and problems." This is an 'epistemology' (to use the term loosely) of hyper-fragmentation, of the multiplication of difference and the denial of commonality and universality, which by reductio ad absurdum leads to the following point. 
d) The position that no-one can legitimately make claims or conduct analyses beyond their own individual locality and subjectivity. It is thus decolonial not Western epistemology that renders the subaltern unable to speak.

In conclusion, decolonial epistemology undermines its own liberatory aspirations. The misplaced emphasis on the relation between epistemology and socio-political domination in Latin America not only diverts attention from the political, social and economic structures that are responsible for the ideological distortion of reality and the legitimation of all kinds of practices of domination in Latin America and elsewhere, but also threatens to delegitimize an epistemological perspective - based on the best in the Cartesian and empiricist traditions - that can, as the decolonial theory and practice of interculturality also does, contribute to building bridges across cultures and oppressed peoples, as well as undermine and expose the often illegitimate pretensions of those individuals and institutions that wield enormous power.

(Recebido para publicação em 29 de janeiro de 2019)

(Reapresentado em 21 de junho de 2019)

(Aprovado para publicação em 2 de agosto de 2019)

\section{NOTES}

1. The decolonial thinkers addressed in this article focus mainly on Descartes as representative of what they call Western epistemology. Because their claims about Descartes are fundamental to their epistemological arguments, my view is that the weakness of these arguments (and more generally the weakness of their arguments in relation to science) undermines the epistemological aspect of the coloniality of knowledge thesis. However, a separate issue, which for reasons of space cannot be dealt with in this article, is that decolonial thinkers do not provide convincing arguments about how Western epistemology, as opposed to Western political and economic practices, has had the domination effects they claim it has had. Although they claim that these practices and effects are influenced, if not caused by, Western epistemological categories, their arguments, when they are not simply assertions, are unconvincing.

2. In the Daubert v. Merrell Dow Pharm Inc. court case (1993), the U.S. Supreme Court denied the admissibility of evidence that had not been generated by the use of the "scientific method". However, in Kumho Tire Co. v Carmichael (1999), the same Court changed this decision and established that the fundamental criterion is that the evidence presented be reliable, whether or not it is generated through the scientific method - see Haack (2014:104-121).

3. In relation to the subject-object epistemology presupposed by Descartes, why is it problematic for me to conceive myself as separate from and different in nature to, say, 
a tree or a polar bear? If these are not external to me this entails a lot of very strange epistemic and ontological problems (see Russell, 1945:809).

4. One of the greatest philosophers of the $20^{\text {th }}$ century, Bertrand Russell did not share this interpretation of the subject-object relation. Although he thought the distinction between subject and object was necessary, he writes: "In contemplation [...] we start from the not-Self, and through its greatness the boundaries of Self are enlarged; through the infinity of the universe the mind which contemplates it achieves some share in infinity" (Russell, 1998:92).

5. Although it is not clear which "various peoples" Descartes is referring to - they might be other European cultures, since Descartes travelled fairly extensively in Europe -, there is no reason to suppose that Descartes would not have in mind simply any culture different to his own, i.e. that of the dominant European powers.

6. However, Comte certainly did believe in the superiority of "Western civilization", which he also imbued with a racist outlook. For example, in his magnum opus Comte writes: "When we have learned what to look for from the elite of humanity, we shall know how the superior portion should intervene for the advantage of the inferior" (Comte, 2000:6). Nevertheless, such a repugnant value judgement arguably does not impugn Comte's epistemological assumptions. Of course, such ideological views could certainly lead to conceptual and analytical biases, but this cannot be assumed a priori. Both Hegel and Marx, albeit to very different degrees, also held racist beliefs that inevitably shaped and limited their views, yet this does not epistemologically invalidate, for example, Enrique Dussel's philosophy and account of social science just because his own theoretical framework has been forged with (and against) some of the concepts and theories of these thinkers - just as Dussel's heavy reliance on Heidegger (who also held some repugnant views) does not invalidate his entire approach.

7. Author's translation from the Spanish.

8. Author's translation from the Spanish.

9. Author's translation from the Spanish.

10. Author's translation from the Spanish.

11. Author's translation from the Spanish.

12. Richard Rorty is arguably the most influential philosophical exponent of postmodern epistemology. See Susan Haack (1997).

13. As John Cottingham (1992) points out, Descartes certainly held that the mind was a completely different substance to the body - as "blood is distinct from bone", in Descartes' words. However, this does not imply the debasement or "objectification" of the body, as decolonial thinkers claim. As I have shown in discussing the work of Quijano, Descartes holds that the mind is intimately connected to the body. Theodore Brown (1989:325) writes: "As outstanding scholars have recently pointed out, Descartes' philosophical position can best be characterized as 'dualistic interactionism'; readings of Cartesian philosophy that fail to discover his repeated insistence on the centrality of mind-body union are merely 'hasty' and 'superficial glosses'".

14. What does "the quantitative indeterminacy of any quality" actually mean? 


\section{Paul Anthony Chambers}

15. See p. 14 above.

16. Jacob also points out that, contrary to Castro-Gómez's assertion, scientific activity was fully embodied in the everyday life of people from a range of social classes.

17. Castro-Gómez simply follows Foucault, whom he interprets as claiming that rationalism and empiricism constitute part of the same "episteme" (see Castro-Gómez, 201:168).

18. Castro-Gómez cites the Spanish version (see Castro-Gómez, 2005:28).

19. Mignolo's relativism questions the objective basis of actual reality. See Mignolo (2011:100).

20. Boaventura de Sousa Santos also adopts a relativist stance. He claims that "the universal validity of a scientific truth is admittedly always very relative, given the fact that it can only be ascertained in relation to certain kinds of objects under certain circumstances and established by certain methods" (Santos, 2014:119). 


\section{REFERENCES}

ALLAIS, Lucy. (2016), “Kant's Racism”. Philosophical Papers , v. 45, n. 1-2 , pp. 1-36.

BAQUERO, Sergio Ángel; ORTIZ, Julián Andrés Caicedo e NOGUERA, Juan Carlos Rico. (2015), “Colonialidad del Saber y Ciencias Sociales: Una Metodología para Aprehender los Imaginarios Colonizados". Análisis Político, v. 28, n. 85 , pp. 76-92.

BRACKEN, Harry M. (2002), Descartes. Oxford, Oneworld.

BROWN, Theodore. (1989), "Cartesian Dualism and Psychosomatics". Psychosomatics, v. 30, n. 3, pp. 322-331.

CAÑIZARES-ESGUERRA, Jorge and CUETO, Marcos. (2002), "Latin American Science: The Long View". NACLA Report on the Americas, v. 35, n. 5, pp. 18-22.

CASTRO-GÓMEZ, Santiago. (2005), La Hybris del Punto Cero. Ciencia, Raza e Ilustración en la Nueva Granada, 1750-1816. Bogotá, Pontificia Universidad Javeriana.

. (2011), Crítica de la Razón Latinoamericana. Bogotá, Pontificia Universidad Javeriana.

CHAMBERS, Paul A. (2013), "“Guerra Civil Continuada por otros Medios': Las Dimensiones Normativas e Ideológicas del Conocimiento Científico-social e Histórico en torno al Conflicto Armado Colombiano". Estudios Políticos, n. 42, pp. 37-60.

COMTE, Auguste. (2000[1896]). The Positive Philosophy of Auguste Comte. V. 1. London, G. Bell \& Sons.

CORTINA, Regina; MARTIN ALCOFF, Linda; GREEN STOCEL, Abadio e ESTEVA, Gustavo. (2019), "Decolonial Trends in Higher Education: Voices from Latin America". Compare: A Journal of Comparative and International Education, v. 49 n. 3, pp. 489-506.

COTTINGHAM, John (ed.). (1992), The Cambridge Companion to Descartes. Cambridge, Cambridge University Press.

COTTINGHAM, John; STOOTHOFF, Robert e MURDOCH, Dugald. (1985), The Philosophical Writings of Descartes. Vol I. Cambridge, Cambridge University Press.

DESCARTES, René (1996). Meditations on First Philosophy. Available at: Internet Encyclopedia of Philosophy, 1996. This file is of the 1911 edition of The Philosophical Works of Descartes (Cambridge University Press), translated by Elizabeth S. Haldane. Available at: http:/ / selfpace.uconn.edu/class/percep/DescartesMeditations.pdfDOMINGUES, José M. (2009), "Modernity and Modernizing Moves. Latin America in Comparative Perspective". Theory, Culture E Society, v. 26, n. 7-8, pp. 208-227.

DUSSEL, Enrique. (1969), Para una Destrucción de la Historia de la Ética. V. I. S.1., Editorial Ser y Tiempo.

. (1973), Para una Ética de la Liberación Latinoamericana. Tomo I. Buenos Aires, Siglo XXI.

. (1985), Philosophy of Liberation. Maryknoll; New York, Orbis.

. (2014), "Anti-cartesian Meditations: On the Origin of the Philosophical Anti-discourse of Modernity". Journal for Cultural and Religious Theory, v. 13, n. 1, pp. 11-53.

FONTAN, Victoria. (2012), "Replanteando la Epistemología de la Paz: El Caso de la Descolonización de Paz". Perspectivas Internacionales, v. 8, n. 1, pp. 41-71. 


\section{Paul Anthony Chambers}

FREGOSO BAILÓN, Raúl Olmo e DE LISSOVOY, Noah. (2019), Against Coloniality: Toward an Epistemically Insurgent Curriculum. Policy Futures in Education, v. 17, n. 3, pp. 355-369.

GAUKROGER, Stephen. (1997), Descartes. An Intellectual Biography. New York, Oxford University Press.

GO, Julian. (2016), Postcolonial Thought and Social Theory. New York, Oxford University Press.

GROSFOGUEL, Ramón. (2013), “Racismo/Sexismo Epistémico, Universidades Occidentalizadas y los Cuatro Genocidios/Epistemicidios del Largo Siglo XVI". Tabula Rasa, n. 19, pp. 31-58.

HAACK, Susan. (1993), Evidence and Inquiry. Towards Reconstruction in Epistemology. Oxford, Oxford University Press.

. (1997), “Vulgar Rortyism”. The New Criterion, v. 16, n. 3, pp. 67-70.

. (1998), "Reflections on Relativism: From Momentous Tautology to Seductive Contradiction", in S. Haack, Manifesto of a Passionate Moderate. Unfashionable Essays. Chicago/ London, University of Chicago Press, pp. 149-166.

. (2014), Evidence Matters. Science, Proof, and Truth in the Law. Cambridge, Cambridge University Press.

HARVEY, David. (1974), "Population, Resources, and the Ideology of Science". Economic Geography, v. 50, n. 3, 1974, pp. 256-277.

HUME, David. (2009[1740]). A Treatise of Human Nature. Being an Attempt to Introduce the Experimental Method of Reasoning Into Moral Subjects. S.l., The Floating Press.

JACOB, Margaret. (2010), The Scientific Revolution. A Brief History with Documents. Boston/ New York/Bedford, St. Martin's.

KERR, Jeannie. (2014), “Western Epistemic Dominance and Colonial Structures: Considerations for Thought and Practice in Programs of Teacher Education". Decolonization: Indigeneity, Education \& Society, v. 3, n. 2, pp. 83-104.

MANN, Charles C. (2006), 1491. New Revelations of the Americas Before Columbus. New York, Vintage Books.

MIGNOLO, Walter. (1995), “Decires fuera de Lugar: Sujetos Dicentes, Roles Sociales y Formas de Inscripción”. Revista de Crítica Literaria Latinoamericana, v. 21, n. 41, pp. 9-31.

. (2011), The Darker Side of Modernity. Global Futures, Decolonial Options. Durham/ London, Duke University Press.

MILL, John Stuart. (2005[1865]). Auguste Comte and Positivism. S.l., Project Gutenberg. Disponível em https://manybooks.net/titles/milljohn1683316833-8.html.

MOTA DÍAZ, Laura. (2016), “La Colonialidad del Saber en la Enseñanza de Políticas Públicas en Instituciones de Educación Superior en México". Estudios Políticos, n. 49, pp. 239-259.

PATEL, Sujata. (2014), "Afterword: Doing Global Sociology: Issues, Problems and Challenges". Current Sociology, v. 62, n. 4, pp. 603-613. 
QUIJANO, Aníbal. (2000), "Colonialidad del poder, eurocentrismo y América Latina", in E. Lander (ed.), La Colonialidad del Saber: Eurocentrismo y Ciencias Sociales. Perspectivas Latinoamericanas. Buenos Aires, CLACSO, pp. 194-238.

. (2007), "Coloniality and Modernity/Rationality". Cultural Studies, v. 21, n. 2-3, pp. 168-178.

RIVERA CUSICANQUI, Silvia. (2012), "Ch'ixinakax utxiwa: A Reflection on the Practices and Discourses of Decolonization". South Atlantic Quarterly, v. 111, n. 1, pp. 95-109.

ROJAS, Cristina. (2016), "Contesting the Colonial Logics of the International: Toward a Relational Politics for the Pluriverse". International Political Sociology, v. 4, n. 10, pp. 369-382.

RUSSELL, Bertrand. (1945), A History of Western Philosophy. New York, Simon and Schuster. . (1998), The Problems of Philosophy. Oxford, Oxford University Press.

. (2009), The Basic Writings of Bertrand Russell. Abingdon, Routledge.

SAID, Edward. (1979), Orientalism. New York, Vintage Books/ Random House.

SANTOS, Boaventura de Sousa. (2014), Epistemologies of the South. Justice Against Epistemicide. Boulder/ London, Paradigm.

SOKAL, Alan; BRICMONT, Jean. (1999), Intellectual Impostures. Postmodern Philosophers' Abuse of Science. London, Profile Books.

SOTO PIMENTEL, Verónica. (2017), “El Concepto de Matriz de Pensamiento: Una Propuesta Epistemológica Decolonial para el Escenario Actual Latinoamericano". Iconos. Revista de Ciencias Sociales, n. 57, pp. 21-40.

TILLEY, Helen. (2011), Africa as a Living Laboratory: Empire, Development, and the Problem of Scientific Knowledge, 1870-1950. Chicago, University of Chicago Press.

WOOTTON, David. (2015), The Invention of Science. A New History of the Scientific Revolution. New York, Harper. 


\title{
RESUMO
}

Epistemologia e Dominação: Problemas com a Tese da Colonialidade do Conhecimento na Teoria Decolonial Latino-Americana

A teoria decolonial latino-americana é construída em torno da tese da "colonialidade do conhecimento", que afirma que o domínio sociopolítico da América Latina e de outras regiões da periferia global pelos países europeus e pelos Estados Unidos está diretamente relacionado à imposição colonial inicial e à subsequente reprodução cultural da chamada "epistemologia ocidental" e da ciência. Defendo que as reivindicações epistemológicas de quatro pensadores decoloniais (Aníbal Quijano, Walter Mignolo, Enrique Dussel, Santiago Castro-Gómez) que compõem a tese da colonialidade do conhecimento são problemáticas por várias razões: baseiam-se em leituras distorcidas e simplistas de Descartes, Hume e outras figuras do Iluminismo; fazem generalizações controversas sobre a chamada epistemologia ocidental; e, em última instância, levam ao relativismo epistêmico, que é uma base problemática para as ciências sociais e, ao contrário das aspirações decoloniais, torna o subalterno incapaz de falar.

Palavras-chave: colonialidade; teoria decolonial; Descartes; epistemologia; ciência

\begin{abstract}
Epistemology and Domination: Problems with the Coloniality of Knowledge Thesis in Latin American Decolonial Theory
\end{abstract}

Latin American decolonial theory is built around the thesis of the "coloniality of knowledge", which claims that the socio-political domination of Latin America and other regions of the global periphery by European countries and the United States is directly related to the initial colonial imposition and subsequent cultural reproduction of so-called "Western epistemology" and science. I argue that the epistemological claims of four decolonial thinkers (Aníbal Quijano, Walter Mignolo, Enrique Dussel, Santiago Castro-Gómez) that make up the coloniality of knowledge thesis are problematic for several reasons: they are based on distorted and simplistic readings of Descartes, Hume and other Enlightenment figures; they make contentious generalizations about so-called Western epistemology; and they ultimately lead to epistemic relativism, which is a problematic basis for the social sciences and, contrary to decolonial aspirations, renders the subaltern unable to speak.

Keywords: coloniality; decolonial theory; Descartes; epistemology; science 


\section{RÉSUMÉ}

Epistémologie et Domination: Problèmes de Colonisation de la Thèse de la Connaissance en Théorie Décoloniale Latino-Américaine

La théorie décoloniale latino-américaine est construite autour de la thèse de la "colonialité de la connaissance", qui prétend que la domination socio-politique de l'Amérique latine et d'autres régions de la périphérie mondiale par les pays européens et les États-Unis est directement liée à l'imposition coloniale initiale et la reproduction culturelle subséquente de la soi-disant "épistémologie occidentale" et de la science. Je soutiens que les affirmations épistémologiques de quatre penseurs décoloniaux (Aníbal Quijano, Walter Mignolo, Enrique Dussel, Santiago Castro-Gómez) qui composent la thèse de la colonialité de la connaissance sont problématiques pour plusieurs raisons: elles sont basées sur des lectures déformées et simplistes de Descartes, Hume et autres figures des Lumières; ils font des généralisations controversées sur l'épistémologie dite occidentale; et ils conduisent finalement au relativisme épistémique, qui est une base problématique pour les sciences sociales et, contrairement aux aspirations décoloniales, rend le subalterne incapable de parler.

Mots-clés: colonialité; théorie décoloniale; Descartes; épistémologie; science

\section{RESUMEN}

Epistemología y Dominación: Problemas con la Tesis de la Colonialidad del Saber en la Teoría decolonial latinoamericana

La teoría decolonial latinoamericana es construida alrededor de la tesis de la "colonialidad del saber", la cual afirma que la dominación sociopolítica de América Latina y otras regiones de la periferia global, por los países europeos y los Estados Unidos, está directamente relacionada con la imposición colonial inicial y la subsecuente reproducción cultural de la llamada "epistemología occidental" y la ciencia. Argumento que los postulados epistemológicos de cuatro pensadores decoloniales (Aníbal Quijano, Walter Mignolo, Enrique Dussel, Santiago CastroGómez) que componen la tesis de la colonialidad del saber, son problemáticos por varias razones: están basados en lecturas simplistas y distorsionadas de Descartes, Hume y otras figuras de la ilustración; hacen discutibles generalizaciones sobre la llamada epistemología occidental; y conducen al relativismo epistémico, que es una base problemática para las ciencias sociales y, contrario a las aspiraciones decoloniales, hacen que el subalterno sea incapaz de hablar.

Palabras clave: colonialidad; teoría decolonial; Descartes; epistemología; ciencia 